\title{
EVALUASI KINERJA DAN FAKTOR-FAKTOR YANG MEMPENGARUHI PENGGUNAAN ECO JPO GLADHAG PANTI HUSADA KOTA SURAKARTA
}

\author{
Dewi Handayani ${ }^{1)}$, Mulya Gigih Setiawan ${ }^{2)}$ \\ 1)Pengajar Fakultas Teknik, Jurusan Teknik Sipil Universitas sebelas Maret \\ 2)Mahasiswa Fakultas Teknik, Jurusan Teknik Sipil Universitas Sebelas Maret \\ Jl. Ir. Sutami 36 A, Surakarta 57126; Telp. 0271-634524 \\ Email :mulya.gigih@yahoo.co.id
}

\begin{abstract}
Eco Pedestrian Bridges Gladhag Panti Husada is collaboration project between Ministry of Public Work with Surakarta Government. It's located in front of dr. Moewardi Hospital. The purposes of this research are to get customer satisfaction index and priority recommendations for improvement from factors wich affecting the use of Eco Pedestrian Bridges Gladhag Panti Husada. Primary data was obtained with technique spread the questionnaire to Eco Pedestrian Bridges user. The results of the data are grouped into two; respondent characteristic and respondent assessment data. Respondent assessment data are processed with Customer Satisfaction Index (CSI) method to get users satisfaction, while Importance Performance Analysis (IPA) method are to get priority recommendations for improvement from factors which affecting the use of Eco Pedestrian Bridges. The results of user satisfaction index analysis, that's one variable was customer satisfaction index below 50\%. Can be said that the user of Eco Pedestrian Bridges Gladhag Panti Husada good enough with the condition of Eco Pedestrian Bridges. The result of four quadrants analysis, variables which included in the first priority improvement; cleanliness variable and accessibility variable. The priority policies taken include placement of officers to clean the pedestrian bridges, add a trash can, and increased user awareness of cleanliness pedestrian bridges, operating the existing elevator, then repairing the surface of the ramp floor and guiding block.
\end{abstract}

Keywords: Customer Satisfaction Index (CSI), Eco Pedestrian Bridges, Importance Performance Analysis.

\begin{abstract}
Abstrak
Eco JPO Gladhag Panti Husada ialah proyek kerja sama antara Departemen PUPR melalui Pusat Penelitian dan Pengembangan Jalan dan Jembatan ( Pusjatan), Badan Penelitian dan Pengembangan( Balitbang) bersama Pemerintah Kota Surakarta yang berlokasi tepat di depan RSUD dr. Moewardi. Tujuan dari penelitian yaitu untuk mendapatkan tingkat kepuasan pengguna serta rekomendasi prioritas penanganan dari faktor-faktor yang mempengaruhi penggunaan Eco JPO Gladhag Panti Husada. Data primer diperoleh dengan menyebarkan kuisioner kepada pengguna Eco JPO Gladhag Panti Husada. Hasil data yang didapat dibagi menjadi dua, yaitu data karakteristik responden serta data penilaian responden. Dari hasil penilaian responden diolah dengan metode Customer Satisfaction Index (CSI) untuk mendapatkan tingkat kepuasan pengguna serta metode Importance Performance Analysis (IPA) untuk mendapatkan prioritas penanganan faktor-faktor yang mempengaruhi penggunaan Eco JPO Gladhag Panti Husada. Berdasarkan hasil analisis tingkat kepuasan pengguna, didapati terdapat satu variabel dari ketiga belas variabel yang tingkat kepuasannya di bawah 50\% yaitu variabel 11 (kebersihan). Sehingga bisa dikatakan bahwa pengguna Eco JPO Gladhag Panti Husada cukup puas dengan kondisi JPO yang ada saat ini. Kemudian berdasarkan hasil analisis empat kuadaran, didapati variabel yang masuk dalam prioritas penanganan utama yaitu variabel kebersihan serta variabel aksesibilitas. Sehingga kebijakan prioritas yang diutamakan antara lain; untuk variabel kebersihan yaitu pengadaan petugas kebersihan untuk membersihkan area JPO setiap hari, penambahan tempat sampah, serta peningkatan kesadaran pengguna akan kebersihan JPO dengan memasang papan himbauan menjaga kebersihan; untuk varibael aksesibilitas yaitu mengoperasikan lift (elevator) yang ada untuk aksesibilitas penyandang disabilitas dan lansia, memperbaiki permukaan lantai ramp (pelandaian) dan guiding block.
\end{abstract}

Kata Kunci : Customer Satisfaction Index (CSI), Eco JPO (Jembatan Penyeberangan Orang), Importance Performance Analysis (IPA).

\section{PENDAHULUAN}

Eco JPO Gladhag Panti Husada ialah proyek kerja sama antara Departemen PUPR melalui Pusat Penelitian dan Pengembangan Jalan dan Jembatan (Pusjatan) Badan Penelitian dan Pengembangan (Balitbang) bersama Pemerintah Kota Surakarta. Eco JPO tersebut menghubungkan bagian Jalan Kolonel Sutarto sebelah selatan dengan bagian sebelah utara (zona RSUD dokter. Moewardi). JPO tersebut memiliki nama Eco JPO Gladhag Panti Husada. Gladhag yang mempunyai arti jembatan (Bahasa Jawa) dan Panti Husada mempunyai arti tempat ataupun rumah buat kesembuhan.

Eco JPO memiliki konsep yang berkelanjutan yaitu terdiri dari aspek sosial, ekonomi, serta lingkungan. Konsep keberlanjutan dari aspek-aspek tersebut nampak dari desain yang menawan dengan mencermati kearifan lokal, 
fasilitas yang peduli terhadap gender (perbedaan jenis kelamin, umur, serta disabilitas) dan menyediakan sarana buat interaksi sosial. Nilai lebih Eco JPO yang lain antara lain ramah lingkungan (environmental friendly) dengan memanfaatkan air hujan yang ditampung dalam ground water tank untuk menyiram taman, energi mandiri (energy self sufficient) dengan pemakaian solar panel sebagai sumber energi penerangan lampu pada bentang utama JPO, aman (safety) dengan mempraktikkan fitur keamanan di area bentang utama serta bagian tangga serta lift, kemudian artistic (artistic) dengan pemakaian oranmen-ornamen wayang, ukiran batik, serta desain bangunan arsitektural dengan mengangkat budaya lokal.

Fasilitas Eco JPO Gladhag Panti Husada saat ini tampak belum memenuhi tujuan-tujuan utama dari pembangunan JPO. Dari pengamatan lapangan tampak para pejalan kaki masih lebih memilih untuk tidak menggunakan JPO tersebut dengan menyeberang langsung di jalan. Selain itu, perawatan JPO juga tampak kurang diperhatikan sehingga tampak kurang bersih dan banyak tanaman yang mati. Oleh karena itu dirasa penting untuk melakukan penelitian tingkat kepuasan pengguna JPO, dan tingkat harapan pengguna JPO. Dari gambaran tingkat, kepuasan, dan harapan pelanggan tersebut akan dapat direkomendasikan prioritas penanganan berdasarkan faktor-faktor yang berpengaruh dalam penggunaan Eco JPO Gladhag Panti Husada.

\section{METODE}

Metode pengambilan data primer pada penelitian ini dilakukan dengan survei penyeberang jalan, serta wawancara dan pengisisan kuisioner kepada responden terpilih. Observasi, survei wawancara dan pengisian kuisioner dilakukan langsung kepada 108 responden. Lokasi tempat pengambilan data dilakukan di Eco JPO Gladhag Panti Husada (depan RSUD dr. Moewardi), Jalan Kolonel Sutarto, Kota Surakarta. Hasil dari pengumpulan data tersebut dibagi menjadi dua yaitu data karakteristik dan data penilaian responden. Hasil dari kuisioner tersebut dianalisis untuk mendapatkan tingkat kepuasan pengguna Eco JPO Gladhag Panti Husada dengan menggunakan metode Customer Satifaction Index (CSI), serta untuk mendapatkan rekomendasi prioritas penanganan berdasarkan faktor-faktor yang berpengaruh dalam penggunaan Eco JPO Gladhag Panti Husada dengan menggunakan metode Importance Performance Analysis (IPA).

\section{Jembatan Penyeberangan Orang (JPO)}

Menurut Tata Cara Perencanaan Jembatan Penyeberangan untuk Pejalan Kaki di Perkotaan No. 027/T/Bt/1995, "Jembatan penyeberangan pejalan kaki adalah jembatan yang hanya diperuntukkan bagi lalu lintas pejalan kaki yang berfungsi melewatkan lalu lintas yang terputus pada kedua ujung jalan akibat adanya hambatan berupa sungai, saluran, kanal, selat, lembah serta jalan dan jalan kereta api yang menyilang."

Dalam penelitian Harahap,H.H (2014), John J. Fruin (1971) mengatakan "Dalam perencanaan fasilitas bagi pejalan kaki, termasuk fasilitas penyeberangan harus memperhatikan tujuh sasaran utama yaitu : keselamatan (safety), keamanan (security), kemudahan (convenience), kelancaran (continuity), kenyamanan (comfort), keterpaduan sistem (system coherence), dan daya Tarik (attractiveness). Ketujuh faktor tersebut saling berhubungan (inter-related) dan saling tumpang tindih (overlapping). Perubahan salah satu faktor akan mempengaruhi perubahan faktor yang lain."

\section{Perencanaan Teknis Fasilitas Jembatan Penyeberangan Orang}

Menurut Pedoman Kementerian Pekerjaan Umum dan Perumahan Rakyat Pd 03 - 2017 - B Perencanaan Teknis Fasilitas Pejalan Kaki, Jembatan Penyeberangan Orang (JPO) termasuk dalam fasilitas pejalan kaki yang digolongkan dalam penyeberangan pejalan kaki tidak sebidang. Penggunaan jalur penyeberangan tidak sebidang jika telah memenuhi kriteria yang telah ditentukan.

Beberapa ketentuan harus diperhatikan dalam perencanaan fasilitas penyeberangan tidak sebidang:

1. Penyeberangan tidak sebidang harus dapat diakses dengan mudah oleh penyandang cacat, misal dengan penambahan ram (pelandaian) atau dengan elevator;

2. Fasilitas penyeberangan tersebut harus dilengkapi dengan dengan pencahayaan yang baik yang dapat meningkatkan keamanan bagi pejalan kaki;

3. Lokasi dan bangunan harus memperhatikan nilai estetika serta kebutuhan pejalan kaki.

Adapun teknis dalam perencanaan Jembatan Penyeberangan Orang adalah sebagai berikut:

1. Ketentuan teknis konstruksi jembatan penyeberangan mengikuti No. 027/T/Bt/1995 tentang Tata cara perencanaan jembatan penyeberangan untuk pejalan kaki di kawasan perkotaan;

2. Jembatan penyeberangan pejalan kaki merupakan bangunan jembatan yang diperuntukkan untuk menyeberang pejalan kaki dari satu sisi jalan ke sisi jalan yang lainnya. Jembatan penyeberangan pejalan kaki harus dibangun dengan konstruksi yang kuat dan mudah dipelihara. 
3. Jembatan penyeberangan pejalan kaki memiliki lebar minimum 2 (dua) meter dan kelandaian tangga maksimum $20^{\circ}$;

4. Bila jembatan penyeberangan juga diperuntukkan bagi sepeda, maka lebar minimal adalah 2,75 m;

5. Jembatan penyeberangan pejalan kaki harus dilengkapi dengan pagar yang memadai;

6. Pada bagian tengah tangga jembatan penyeberangan pejalan kaki harus dilengkapi pelandaian yang dapat digunakan sebagai fasilitas untuk kursi roda bagi penyandang cacat;

7. Lokasi dan bangunan jembatan penyeberangan pejalan kaki harus sesuai dengan kebutuhan pejalan kaki dan estetika;

8. Penempatan jembatan tidak boleh mengurangi efektivitas trotoar

\section{Metode Importance Performance Analysis (IPA)}

Idris, Zilhardi (2009) pada penelitian Kurniawan, Harry (2018) menyebutkan "Importance Performance Analysis (IPA) merupakan alat bantu dalam menganalisis atau membandingkan sejauh mana kinerja/pelayanan yang dapat dirasakan oleh pengguna jasa dibandingkan terhadap tingkat kepuasan yang diinginkan. Untuk mengukur tingkat kepentingan dan tingkat kepuasan/kinerja terhadap jawaban responden, digunakan skala 5 tingkat (skala Likert). Dari hasil evaluasi tingkatan kepentingan serta kinerja, sehingga akan didapat sesuatu perhitungan tingkatan kesesuaian antara tingkatan kepentingan serta tingkatan pelaksanaannya oleh penyedia jasa. Tingkatan kesesuaian ialah hasil perbandingan antara skor kinerja pelaksanaan dengan skor kepentingan." Sehingga tingkat kesesuaian tersebut yang akan memutuskan skala prioritas yang hendak digunakan dalam pengendalian faktor- faktor yang mempengaruhi kepuasan pengguna Eco JPO Gladhag Panti Husada Kota Surakarta.

Dua buah variabel yang menentukan tingkat kinerja penyedia jasa pelayanan yaitu menggunakan symbol X dan tingkat kepentingan pengguna jasa pelayanan menggunakan simbol $\mathrm{Y}$ seperti yang dijelaskan pada model matematika di bawah ini :

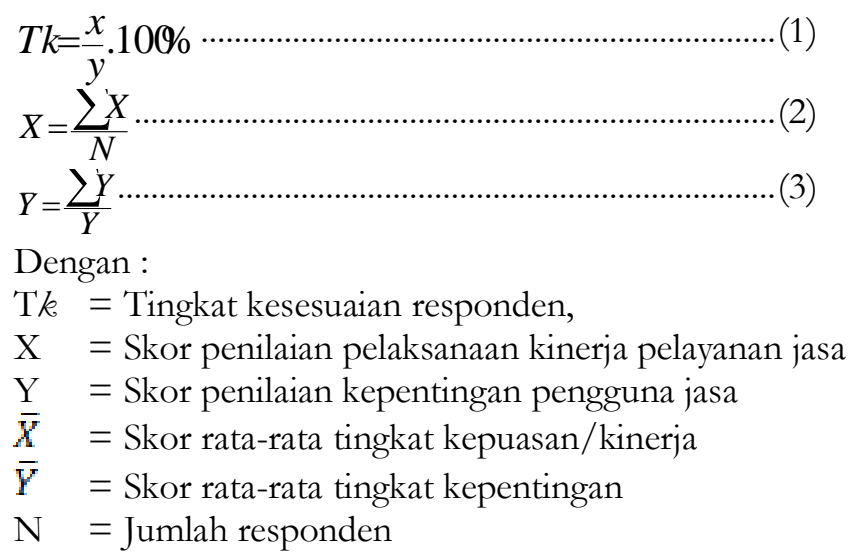

Selanjutnya, tingkat unsur-unsur atau pemetaan dari atribut akan dijabarkan atau dikelompokkan dalam salah satu dari empat kuadran yang disebut dengan diagram kartesius yang dibatasi oleh sumbu $\mathrm{X}$ dan sumbu $\mathrm{Y}$, seperti terlihat dari diagram di bawah ini.

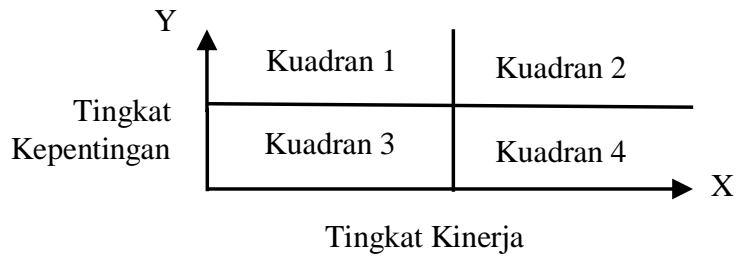

Gambar 1. Importance-Performance Grid diagram kartesius

Pengertian dari empat kuadran diagram kartesius tersebut di atas adalah sebagai berikut :

1. Kuadran 1 : Kepentingan tinggi sebaliknya kinerja rendah, maknanya dalam keadaan tersebut, dari sisi kepentingan pemakai jasa, dimana faktor-faktor yang mempengaruhi pelayanan memiliki tingkatan tinggi, sebaliknya dari sisi kepuasan, pemakai merasakan tingkatan yang rendah (tidak puas) jadi harus terdapatnya perbaikan yang dilakukan penyedia jasa. 
2. Kuadran 2 : Kepentingan tinggi sebaliknya kinerja pula tinggi, maknanya dalam keadaan tersebut, dari sisi pemakai jasa, faktor-faktor yang mempengaruhi pelayanan memiliki tingkatan yang tinggi, sebaliknya kepuasan pemakai jasa pula memiliki tingkatan yang tinggi (telah puas). Pada perihal tersebut penyedia jasa diminta bisa menjaga pelayanan/kinerjanya.

3. Kuadran 3 : Kepentingan rendah sebaliknya kinerja pula rendah, maknanya dalam keadaan tersebut, faktorfaktor yang terkait pada pelayanan tidak berarti untuk pemakai, kinerja penyedia jasa standar-standar saja serta pemakai tidak puas dengan pelayanan yang ada.

4. Kuadran 4 : Kepentingan rendah sebaliknya kinerja tinggi, maknanya dalam keadaan tersebut aspek-aspek yang pengaruhi pelayanan tidak berarti untuk pemakai, tetapi pemakai telah merasa puas.

\section{Metode Customer Satisfaction Index (CSI) / Indeks Kepuasan Pelanggan}

Untuk menentukan ataupun mengukur tingkatan kepuasan pelanggan bisa didetetapkan dengan indikator nilai CSI yang memperhitungkan tingkatan harapan pemakai jasa terhadap faktor- faktor yang hendak ditentukan. Dari penelitian yang dilakukan oleh Syukri, S., H., A, (2014) nilai kepuasan pemakai digolongkan seperti di bawah ini :

Tabel 1. Rekomendasi nilai CSI

\begin{tabular}{cc}
\hline Angka Indeks & Interpretasi Nilai CSI \\
\hline $\mathrm{X} \leq 64 \%$ & Very Poor \\
$64 \%<\mathrm{X} \leq 71 \%$ & Poor \\
$71 \%<\mathrm{X} \leq 77 \%$ & Cause For Concern \\
$77 \%<\mathrm{X} \leq 80 \%$ & Border Line \\
$80 \%<\mathrm{X} \leq 84 \%$ & Good \\
$84 \%<\mathrm{X} \leq 87 \%$ & Very Good \\
$>87 \%$ & Excellent \\
\hline
\end{tabular}

Sumber : Syukri, S., H., A, (2014)

\section{HASIL DAN PEMBAHASAN}

\section{Karakteristik Responden Berdasarkan Jenis Kelamin}

Jumlah responden berdasarkan jenis kelamin yang terlibat dalam penelitian jumlahnya mendekati balance, yaitu jumlah antara responden laki-laki dan jumlah responden perempuan hampir seimbang. Responden dengan jenis kelamin laki-laki dengan persentase $52,78 \%$ dan responden dengan jenis kelamin perempuan dengan persentase $47,22 \%$.

\section{Karakteristik Responden Berdasarkan Usia}

Pengguna Eco JPO Gladhag Panti Husada yang menjadi responden dalam penelitian terbanyak pada rentang usia 21-30 tahun dengan persentase 38,89\%, kemudian disusul pada kelompok usia 31-40 tahun dengan persentase 20,37\%, selanjutnya kelompok usia 17-20 tahun dengan persentase 14,81\%, kelompok usia 41-50 tahun dengan persentase $14,81 \%$, lalu kelompok usia $>50$ tahun dengan persentase 10,19\%, dan untuk kelompok usia $<17$ tahun dengan persentase $0,93 \%$. Variasi responden berdasarkan usia menurut hasil suvei utama ditunjukkan pada Gambar 2. berikut ini :

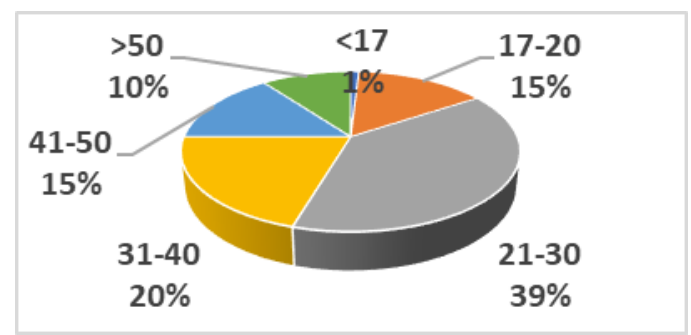

Gambar 2. Grafik karakteristik responden berdasarkan usia

\section{Karakteristik Responden Berdasarkan Pendidikan Terakhir}

Jumlah responden pengguna Eco JPO Gladhag Panti Husada yang terlibat dalam penelitian ini, memiliki latar belakang pendidikan SMA terbanyak dengan persentase 50\%, selanjutnya S1 dengan persentase $28,70 \%$, kemudian disusul Diploma dengan persentase 8,33\%, lalu SMP dengan persentase 6,48\%, sesudah itu SD dengan per- 
Jurnal Matriks Teknik Sipil

DOI: https://doi.org/10.20961/mateksi.v8i3

ISSN: $2354-8630$

E-ISSN: 2723-4223

Vol 8, No 3 (2020): September

sentase $4,63 \%$, seterusnya S2/S3 dengan persentase $0,93 \%$, dan dengan pendidikan terakhir lainnya dengan persentase $0,93 \%$. Keragaman responden berdasarkan pendidikan terakhir dapat ditunjukkan seperti Gambar 3 . berikut :

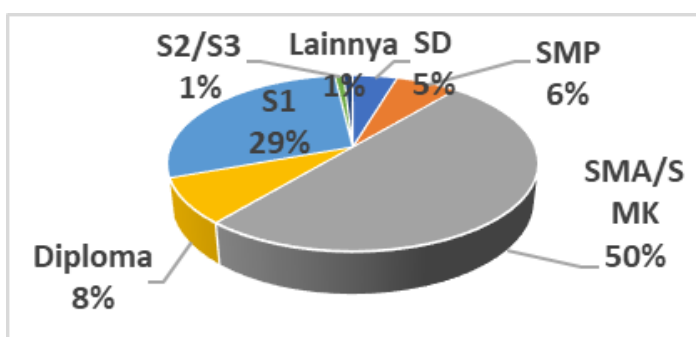

Gambar 3. Grafik karakteristik responden berdasarkan pendidikan terakhir

\section{Karakteristik Responden Berdasarkan Jenis Pekerjaan}

Responden pengguna Eco JPO Gladhag Panti Husada paling banyak berprofesi sebagai wiraswasta/professional dengan persentase 29,63\%, disusul pegawai swasta dengan persentase 18,52\%, kemudian pelajar/mahasiswa dengan persentase 17,59\%, kemudian lain-lain dengan persentase 13\%, selanjutnya PNS/TNI/POLRI dengan persentase 11,11\%, dan tenaga kesehatan dengan persentase 11,11\%. Keragaman responden menurut jenis pekerjaan dapat ditunjukkan seperti Gambar 4. berikut:

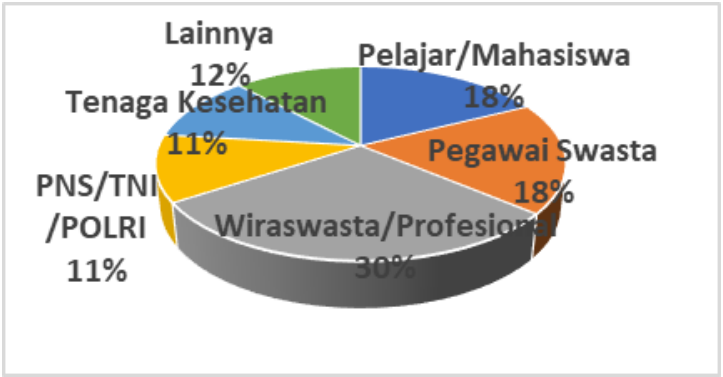

Gambar 4. Grafik karakteristik responden berdasarkan jenis pekerjaan

\section{PEMBAHASAN}

\section{Tingkat Kepuasan Pengguna Eco JPO Gladhag Panti Husada}

Hasil dari analisis pembacaan nilai Customer Satisfaction Index (CSI) dari 13 indikator/variabel Eco JPO yang dipertanyakan, memperlihatkan bahwa pelayanan yang ada cukup baik. Kondisi ini nampak berdasarkan nilai perbandingan diantara tingkatan kinerja/kepuasan dan tingkatan kepentingan/harapan pengguna Eco JPO Gladhag Panti Husada.

Tabel 3. Tingkatan rasio, bobot kinerja, serta bobot harapan responden terhadap eco jpo gladhag panti husada

\begin{tabular}{|c|c|c|c|c|c|c|c|}
\hline No & Indikator & $\begin{array}{l}\text { Bobot } \\
\text { Kinerja }\end{array}$ & $\begin{array}{l}\text { Bobot } \\
\text { Harapan }\end{array}$ & $\begin{array}{l}\text { Tingkat } \\
\text { Kesesuaian } \\
(\%)\end{array}$ & $\begin{array}{l}\text { Yang } \\
\text { Sesuai } \\
(\%) \\
\end{array}$ & Belum & $\begin{array}{l}\text { Interpretasi } \\
\text { CSI }\end{array}$ \\
\hline 1. & Keselamatan penyeberang jalan & 443 & 510 & 86,86 & 13,14 & & Verry Good \\
\hline 2. & $\begin{array}{l}\text { Penerangan pada jembatan } \\
\text { penyeberangan }\end{array}$ & 407 & 493 & 82,56 & 17,44 & & Good \\
\hline 3. & $\begin{array}{l}\text { Keamanan pengguna jembatan } \\
\text { penyeberangan }\end{array}$ & 408 & 497 & 82,09 & 17,91 & & Good \\
\hline 4. & Tinggi dan lebar anak tangga & 381 & 460 & 82,83 & 17,17 & & Good \\
\hline 5. & $\begin{array}{l}\text { Luas area untuk berjalan di Eco } \\
\text { JPO }\end{array}$ & 423 & 444 & 95,27 & 4,73 & & Excellent \\
\hline 6. & $\begin{array}{l}\text { Keteduhan jembatan penyeber- } \\
\text { angan }\end{array}$ & 429 & 456 & 94,08 & 5,92 & & Excellent \\
\hline 7. & $\begin{array}{l}\text { Jarak ke/dari pemberhentian sa- } \\
\text { rana angkutan umum (halte) }\end{array}$ & 430 & 456 & 94,30 & 5,70 & & Excellent \\
\hline 8. & $\begin{array}{l}\text { Jarak ke/dari pusat kegiatan } \\
\text { (RSUD dr Moewardi) }\end{array}$ & 450 & 472 & 95,34 & 4,66 & & Excellent \\
\hline 9. & $\begin{array}{l}\text { Taman pada jembatan penyeber- } \\
\text { angan }\end{array}$ & 238 & 407 & 58,48 & 41,52 & & Very Poor \\
\hline 10. & $\begin{array}{l}\text { Fasilitas tempat duduk dan charg- } \\
\text { ing pada JPO }\end{array}$ & 320 & 438 & 73,06 & 26,94 & & $\begin{array}{l}\text { Cause for Con- } \\
\text { cern }\end{array}$ \\
\hline
\end{tabular}




$\begin{array}{ll}498 & 49,20 \\ 494 & 61,13 \\ & \\ 434 & 97,24\end{array}$

Vol 8, No 3 (2020): September

Hasil analisis interpretasi nilai Customer Satisfaction Index (CSI) berdasarkan penilaian kepuasan pengguna Eco JPO Gladhag Panti Husada adalah sebagai berikut :

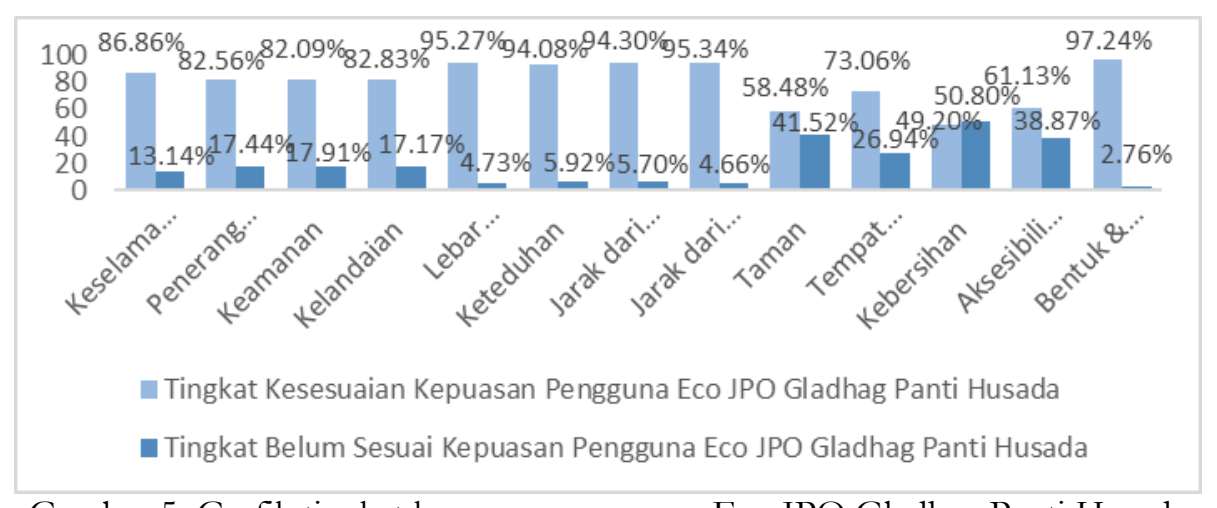

Gambar 5. Grafik tingkat kepuasan pengguna Eco JPO Gladhag Panti Husada

Hasil pengelompokkan 13 indikator pelayanan berdasarkan interpretasi CSI tersebut dari ketiga belas variabel terdapat satu variabel yang tingkat kepuasannya dibawah $50 \%$ yaitu variabel 11 (kebersihan). Hal tersebut menunjukkan bahwa tingkat kepuasan Eco JPO Gladhag Panti Husada sudah cukup baik. Bisa dikatakan bahwa pengguna Eco JPO Gladhag Panti Husada cukup puas atas kondisi Eco JPO saat ini. Pembacaan nilai CSI juga memperlihatkan bahwa parameter taman pada Eco JPO, kebersihan Eco JPO, dan aksesibilitas Eco JPO untuk penyandang disabilitas dan lansia harus ditingkatkan supaya penyeberang jalan merasa aman dan nyaman memakai Eco JPO Gladhag Panti Husada. Berikut ini pembahasan setiap kategori tingkat kepuasan.

\section{Analisis Empat Kuadran dengan Importance Performance Analysis (IPA)}

Hasil dari pengumpulan data penilaian yang diperoleh akan dianalisis dengan menggunakan metode Importance Performance Anlaysis (IPA). Analisis ini dilakukan dengan alat bantu Ms. Excel.

Tabel 4. Analisis empat kuadran

\begin{tabular}{|c|c|c|c|c|c|c|}
\hline No & Indikator & $\begin{array}{l}\text { Bobot } \\
\text { Kinerja }\end{array}$ & $\begin{array}{l}\text { Bobot } \\
\text { Kepentingan }\end{array}$ & $\begin{array}{l}\text { Jumlah } \\
\text { Responden }\end{array}$ & $\overline{\bar{X}}$ & $\bar{Y}$ \\
\hline 1. & Keselamatan penyeberang jalan & 443 & 510 & 108 & 4,10 & 4,72 \\
\hline 2. & $\begin{array}{l}\text { Penerangan pada jembatan } \\
\text { penyeberangan }\end{array}$ & 407 & 493 & 108 & 3,77 & 4,56 \\
\hline 3. & $\begin{array}{l}\text { Keamanan pengguna jembatan } \\
\text { penyeberangan }\end{array}$ & 408 & 497 & 108 & 3,78 & 4,60 \\
\hline 4. & Tinggi dan lebar anak tangga & 381 & 460 & 108 & 3,53 & 4,26 \\
\hline 5. & $\begin{array}{l}\text { Luas area untuk berjalan di Eco } \\
\text { JPO }\end{array}$ & 423 & 444 & 108 & 3,92 & 4,11 \\
\hline 6. & $\begin{array}{l}\text { Keteduhan jembatan penyeber- } \\
\text { angan }\end{array}$ & 429 & 456 & 108 & 3,97 & 4,22 \\
\hline 7. & $\begin{array}{l}\text { Jarak ke/dari pemberhentian sa- } \\
\text { rana angkutan umum (halte) }\end{array}$ & 430 & 456 & 108 & 3,98 & 4,22 \\
\hline 8. & $\begin{array}{l}\text { Jarak ke/dari pusat kegiatan } \\
\text { (RSUD dr Moewardi) }\end{array}$ & 450 & 472 & 108 & 4,17 & 4,37 \\
\hline 9. & $\begin{array}{l}\text { Taman pada jembatan penyeber- } \\
\text { angan }\end{array}$ & 238 & 407 & 108 & 2,20 & 3,77 \\
\hline 10. & $\begin{array}{l}\text { Fasilitas tempat duduk dan charg- } \\
\text { ing pada JPO }\end{array}$ & 320 & 438 & 108 & 2,96 & 4,06 \\
\hline 11. & Kebersihan JPO & 245 & 498 & 108 & 2,27 & 4,61 \\
\hline 12. & $\begin{array}{l}\text { Mudah diakses oleh penyandang } \\
\text { disabilitas dan lansia }\end{array}$ & 302 & 494 & 108 & 2,80 & 4,57 \\
\hline 13. & $\begin{array}{l}\text { Bentuk dan keindahan desain } \\
\text { JPO }\end{array}$ & 422 & 434 & 108 & 3,91 & 4,02 \\
\hline \multicolumn{5}{|c|}{ Nilai Rata-Rata } & 3,49 & 4,32 \\
\hline
\end{tabular}


Hasil pembacaan plotting variabel dalam empat kuadran sebagai berikut :

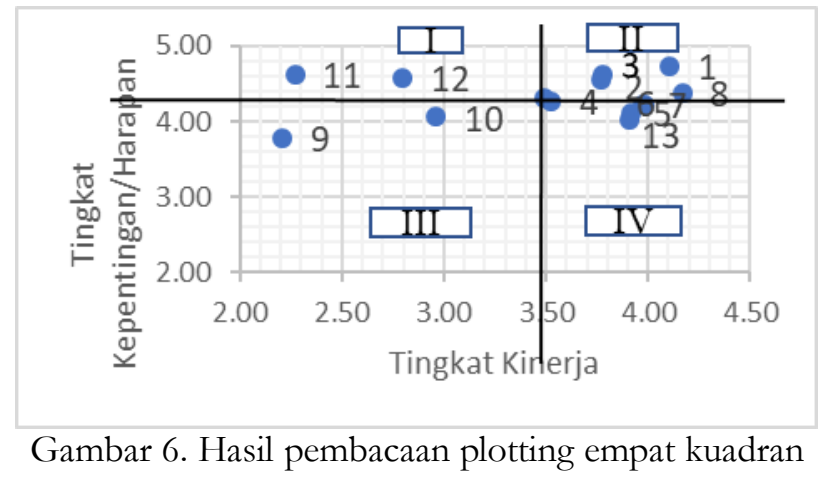

Hasil plotting Ms. Excel tersebut dapat dilihat pada Tabel 5. berikut ini :

Tabel 5. Hasil analisis empat kuadran penilaian responden pengguna Eco JPO Gladhag Panti Husada

\begin{tabular}{ccl}
\hline Hasil & No. Variabel & \multicolumn{1}{c}{ Variabel } \\
\hline Kuadran 1 & 11 & Kebersihan JPO \\
(Concentrate These) & 12 & Aksesibilitas untuk penyandang disabilitas dan lansia \\
\hline Kuadran 2 & 1 & Keselamatan pengguna JPO \\
(Keep Up The Good Work) & 2 & Penerangan JPO \\
& 3 & Keamanan JPO \\
& 8 & Jarak ke/dari pusat kegiatan (RSUD dr Moewardi) \\
\hline Kuadran 3 & 9 & Taman pada JPO \\
(Low Priority) & 10 & Fasilitas tempat duduk dan charging \\
\hline Kuadran 4 & 4 & Kelandaian anak tangga JPO \\
(Possible Overkill) & 5 & Lebar area untuk berjalan \\
& 6 & Keteduhan JPO \\
& 7 & Jarak ke/dari tempat pemberhentian angkutan umum \\
& & (halte) \\
& 13 & Bentuk dan keindahan desain JPO
\end{tabular}

Pada hasil olahan di atas (tabel 4.12) didapati hasil yang terletak dalam kuadran 1 atau prioritas pertama adalah variabel 11 dan variabel 12. Hal ini menunjukkan bahwa kedua variabel tersebut menurut responden pengguna Eco JPO Gladhag Panti Husada harus dilakukan perbaikan karena memiliki kepentingan yang tinggi, namun kinerja yang dirasakan rendah.

Pada kuadran 2 didapati variabel 1, variabel 2, variabel 3, dan variabel 8. Hal ini menunjukkan responden pengguna Eco JPO Gladhag Panti Husada menilai keempat variabel tersebut memiliki kinerja yang tinggi dengan tingkat kepentingan yang tinggi. Kedepannya, faktor-faktor dalam empat variabel tersebut harus dilakukan pertahanan dan peningkatan karena memiliki pengaruh yang besar pada pengguna Eco JPO Gladhag Panti Husada.

Pada kuadran 3 diisi oleh variabel 9 dan variabel 10. Hal ini menunjukkan menurut responden pengguna Eco JPO Gladhag Panti Husada, kedua variabel tersebut memiliki tingkat kinerja yang rendah dan tingkat kepentingannya juga rendah. Kedua faktor tersebut tidak perlu dilakukan peningkatan dengan sumber daya paling baik karena memiliki pengaruh yang rendah pada pengguna Eco JPO Gladhag Panti Husada.

Kuadran 4 diisi oleh variabel 4, variabel 5, variabel, 6, variabel 7, dan variabel 13. Hal ini menunjukkan menurut penilaian responden pengguna Eco JPO Gladhag Panti Husada kelima variabel tersebut memiliki kinerja yang baik, tetapi tidak memiliki pengaruh yang besar karena tingkat kepentingannya yang rendah. Kedepannya, kelima variabel tersebut cukup dipertahankan saja apa yang sudah ada saat ini.

\section{KESIMPULAN}

Berdasarkan hasil pengolahan data di Eco JPO Gladhag Panti Husada Kota Surakarta dapat ditarik kesimpulan sebagai berikut : 
1. Hasil pengelompokkan 13 indikator pelayanan berdasarkan interpretasi CSI terdapat satu variabel dari ketiga belas variabel yang tingkat kepuasannya di bawah $50 \%$ yaitu variabel 11 (kebersihan). Jadi bisa dikatakan pengguna Eco JPO Gladhag Panti Husada cukup puas akan kondisi JPO yang ada. Interpretasi CSI pula memperlihatkan bahwa indikator taman pada JPO, kebersihan JPO, dan aksesibilitas JPO untuk penyandang disabilitas dan lansia perlu lebih ditingkatkan supaya penyeberang jalan merasa lebih aman dan lebih nyaman memanfaatkan Eco JPO Gladhag Panti Husada.

2. Kebijakan untuk meningkatkan penggunaan Eco JPO Gladhag Panti Husada adalah sebagai berikut :

a. Kebijakan Prioritas I : Pengadaan petugas kebersihan untuk membersihkan area JPO setiap hari, penambahan tempat sampah pada area JPO, peningkatan kesadaran pengguna tentang kebersihan JPO dengan memasang papan himbauan untuk menjaga kebersihan, mengoperasikan lift (elevator) yang ada untuk aksesibilitas penyandang disabilitas dan lansia, dan memperbaiki permukaan lantai ramp (pelandaian) dan guiding block.

b. Kebijakan Prioritas II : Perawatan dan perbaikan struktur serta bagian pelengkap JPO secara berkala, pemasangan pagar pembatas pada median jalan, perawatan dan perbaikan lampu penerangan pada JPO secara berkala, menempatkan petugas penjaga di JPO, memberi papan petunjuk arah dan tujuan di muka JPO.

c. Kebijakan Prioritas III : Melakukan penanaman kembali taman pada JPO, perawatan taman setiap hari pada JPO bekerja sama dengan Dinas Lingkungan Hidup dan Pertamanan, perbaikan fasilitas tempat duduk, dan perbaikan charging bub.

\section{REFERENSI}

Departemen Pekerjaan Umum, 2017, “Pd 03 - 2017 - B : Perencanaan Teknis Fasilitas Pejalan Kaki”, Dirjen Bina Marga, Jakarta

Direktorat Jendral Bina Marga, 1995, “Tata Cara Perencanaan Jembatan Penyebrangan Untuk Pejalan Kaki di Perkotaan", Departemen Pekerjaan Umum, Jakarta.

Direktorat Bina Teknik Jalan dan Jembatan, 2019,'Kementerian PUPR Bangun JPO Ramah Lingkungan di Solo", http://www.pusjatan.pu.go.id/produk/litbang_detail/eco-jpo-gladhag-panti-husada-surakarta , diakses 6 Februari 2020

Harahap, H., H., 2014, “Analisa Karakteristik Penggunaan Jembatan Penyeberangan Pada Daerah Perbelanjaan di Jalan Jenderal Sudirman Kota Palembang", Universitas Sriwijaya.

Husin, Nabila F, 2018, "Analisis Faktor Prioritas Kegiatan Bersepeda Universitas Sebelas Maret Surakarta”, Skripsi, Jurusan Teknik Sipil, Fakultas Teknik. Universitas Sebelas Maret.

Idris, Z, 2009,'Kajian Tingkat Kepuasan Pengguna Angkutan Umum di DIY”, Dinamika TEKNIK SIPIL, Vol. 9 No. 2, pp. $189-196$.

Janti, Suhar, 2014, "Analisis Validitas dan Reliabilitas Dengan Skala Likert Terhadap Pengembangan Si/Ti Dalam Penetuan Pengambilan Keputusan Penerapan Strategic Planning pada Industri Garmen”, Prosiding Seminar Nasional Aplikasi Sains \& Teknologi, Yogyakarta, 15 November 2014, pp. 155-160

Kurniasari, C Resty, 2012, "Analisis Karakteristik Penumpang dan Persepsi Penumpang terhadap Tingkat Pelayanan Batik Solo Trans di Surakarta”, Skripsi, Jurusan Teknik Sipil. Fakultas Teknik, Universitas Sebelas Maret. Surakarta.

Kurniawan, Harry dan Nadia Khaira Ardi, 2018, "Tingkat Kepuasan Pengguna Fasilitas Penyeberangan Orang (Studi Kasus JPO Muka Kuning Kota Batam)”, Universitas Riau Kepualauan Batam.

Kementerian Pekerjaan Umum, 2014, "Peraturan Menteri Pekerjaan Umum Nomor 03/PRT/M/2014 : Pedoman Perencanaan, Penyediaan, dan Pemanfaatan Prasarana dan Sarana Jaringan Pejalan Kaki di Kawasan Perkotaan", Jakarta, Menteri Pekerjaan Umum.

Kementerian Pekerjaan Umum dan Perumahan Rakyat, 2019, "Kementerian PUPR Bangun JPO Ramah Lingkungan di Solo", https://pu.go.id/berita/kementerian-pupr-bangun-jpo-ramah-lingkungan-di-solo, diakses 6 Februari 2020

Nawir, Daud dan Rusmiyanti, 2019, "Studi Analisis Fasilitas Jembatan Penyeberangan Orang di Kota Tarakan”, Universitas Borneo Tarakan.

Putra, Zahreza FS, 2014, "Analisis Kualitas Layanan Website BTKP-DIY Menggunakan Metode Webqual 4.0", Jurnal JARKOM. Vol. 1 No. 2. Insititut Sains \& Teknologi AKPRIND. Yogyakarta.

Riskawati, 2013, "Uji Validitas dan Reliabilitas". Statistika Pendidikan.com

Sugiyono, 2010, "Metode Penelitian Pendidikan Pendekatan Kuantitatif, Kualitatif, dan R\&D", Alfabeta, Bandung

Syukri, S. H. A., 2014, "Penerapan Customer Satisfaction Index (CSI) dan Analisis Gap Pada Kualitas Pelayanan Trans Jogja", Universitas Islam Negeri Sunan Kalijaga. 